\title{
A NEW VARIETY OF CYRTOCARPA EDULIS (ANACARDIACEAE)
}

\author{
José Luis León de La LuZ y José Juan Pérez Navarro
}

Centro de Investigaciones Biológicas del Noroeste, Apdo. postal 128, 23000 La Paz, Baja California Sur, México

jlleon04@cibnor.mx

\begin{abstract}
Cyrtocarpa edulis var. glabra, an endemic taxon restricted to the southwestern portion of the Baja California Peninsula, is described and illustrated. This new variety only occurs along an arid coastal strip of the Pacific Ocean. The principal character by which it differs from the typical variety is the glabrous condition of the leaves, flowers, and fruits.
\end{abstract}

Key words: Anacardiaceae, Baja California, Cyrtocarpa, Mexico, Pacific coast.

\section{RESUMEN}

Se describe e ilustra a Cyrtocarpa edulis var. glabra, un taxon endémico restringido al sector sud-occidental de la Península de Baja California. Esta nueva variedad sólo ocupa una árida franja costera del Océano Pacífico. La principal característica que la hace diferir de la variedad típica es la condición glabra de las hojas, flores y frutos.

Palabras clave: Anacardiaceae, Baja California, Costa del Pacífico, Cyrtocarpa, México.

Cyrtocarpa (Brandegee) Standley is a genus of five species of American trees: C. velutinifolia (Cowan) J. D. Mitchell \& Daly in Guyana, C. caatingae J. D. Mitchell \& Daly in Brazil, C. procera Kunth and C. kruseana R. M. Fonseca in several southern and western states of Mexico, as well as C. edulis (Brandegee) Standley, which is restricted to the southern portion of the Baja California Peninsula, Mexico (Shreve \& Wiggins, 1964; Wiggins, 1980). Brandegee (1900) described the latter species in the genus Tapirira, once considered a widespread tropical genus, inhabiting as far as northwestern North America (Manchester, 1977) but currently 
restricted to tropical Mexico and southern South America (Terrazas and Wendt, 1995). Later, Standley (1923) transferred this taxon to Cyrtocarpa because of the dense pubescence on fruit and leaves and the straight embryo; in contrast, the leaves of some Tapirira species are densely pubescent, but the fruits are almost glabrous, and the embryo is curved.

The "ciruelo del monte", as C. edulis is commonly known, represents one of the characteristic sarcocaulescent life-forms inhabiting the Cape Region of the Baja California Peninsula, which extends from the southern tip of the peninsula up to parallel $25^{\circ} \mathrm{N}$, and is considered the transition between the dry-subtropical zone and the Sonoran Desert province (León de la Luz et al., 2000). The flesh of the fruit (a drupe) is edible and has a slightly acid taste. Local inhabitants can gather several kilograms from a single wild tree, which they eat or sell in local markets.

Some of these trees grow up to $8 \mathrm{~m}$, their fleshy stems and arms of wooden appearance often exhibit bizarre-looking twisted branches. The plants prefer deep sandy soils and level terrain, but also are found marginally in more arid conditions on back dunes and on islands in the southern Gulf of California. The species also inhabits marginally the dry tropical forest in the mountains of the Cape Region, but it is less abundant there. According to Turner et al. (1995), its distribution in the mountains may be restricted to areas of deep soil and limited by intolerance to shade in the foothills and low winter temperatures in the highlands.

Recently, while collecting plants on the back dunes along the coast of the Pacific shore between the town of Todos Santos and the Magdalena Plains of the Sonoran Desert, we found several individuals of C. edulis that attracted our attention because of the glabrous condition of leaves, flowers, and fruits. After being unable to encounter glabrous plants among specimens of this species in the herbaria of ENCB, $\mathrm{HCIB}$, and $\mathrm{SD}$ we have decided to propose these as a new variety of C. edulis.

Cyrtocarpa edulis (Brandegee) Standley var. glabra León de la Luz \& PérezNavarro var. nov. Fig. 1

C. edulis var. edulis similis, frutex usque $1.5 \mathrm{~m}$ altus; foliolis glabris, calyce, corolla et drupa glabris.

Spreading shrub, with thick trunk up to $1.5 \mathrm{~m}$ high, and then prostrate branches, basal diameter up to $0.30 \mathrm{~m}$; wood soft with smooth pale gray bark. Leaves glabrous, pinnately compound, $4-8 \mathrm{~cm}$ long; leaflets 7 to 11 , elliptic-ovate, $0.8-3 \mathrm{~cm}$ long, obtuse at apex, almost sessile on an almost terete rachis. Flowers white with 


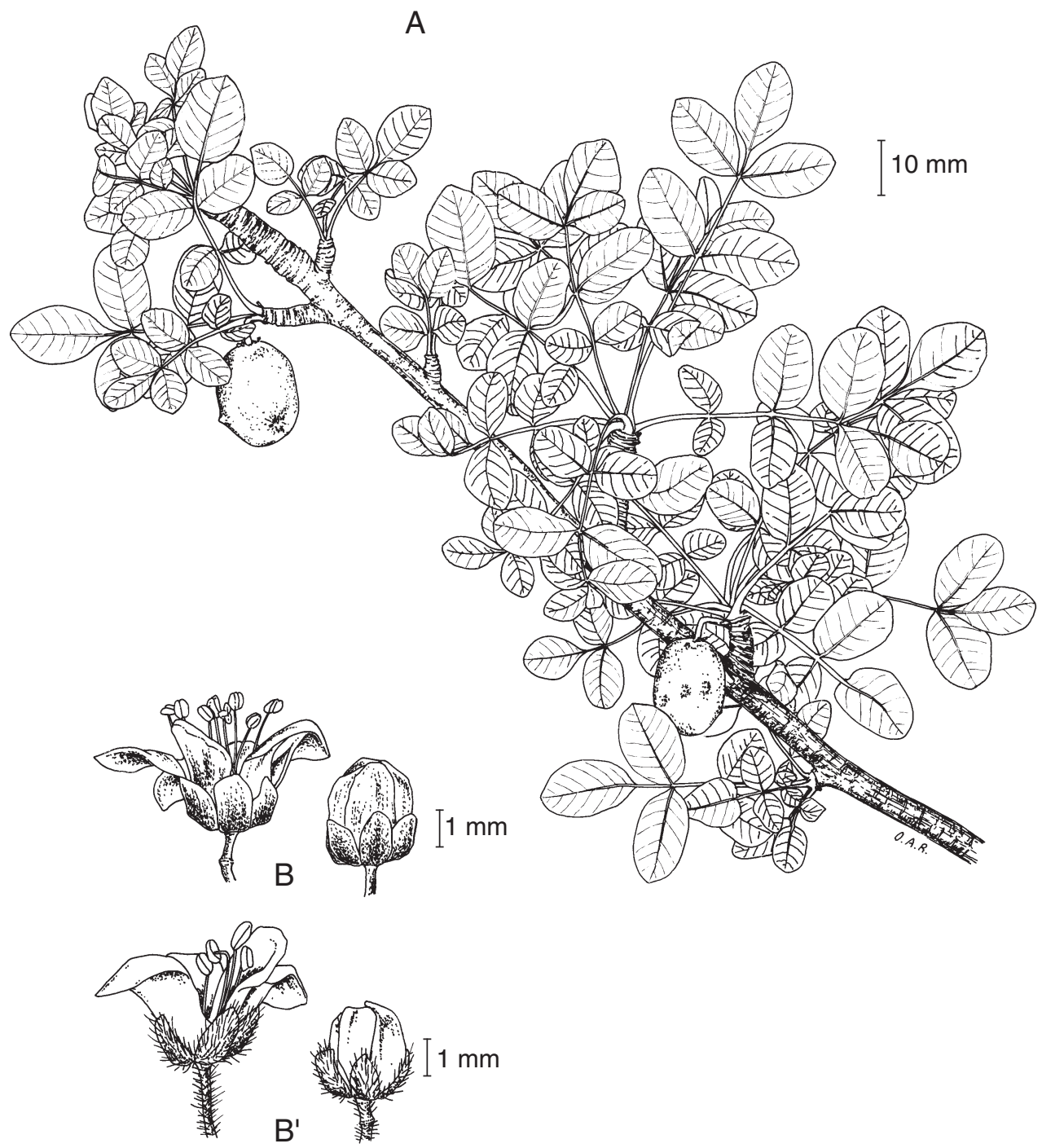

Fig. 1. A. branch of C. edulis var. glabra in fructification (based on José Juan Pérez Navarro 1351); B. flowers of the new variety; sepals are completely glabrous (based on José Juan Pérez Navarro 1278); B'. flowers of the typical variety, showing characteristic trichomes in sepals' outer surface (based on José Luis León de la Luz 7786). 
green shading, sepals glabrous, ca. $1 \mathrm{~mm}$ long, margins scarious, petals $1.5-3 \mathrm{~mm}$ long. Fruit an oblong-ovoid drupe, $1.5-2 \mathrm{~cm}$ long, glabrous, green to yellow when ripe, fleshy with bittersweet taste.

Type: Mexico. Baja California Sur: Boca del Carrizal, $5 \mathrm{~km}$ north of Ejido Melitón Albáñez, municipality of La Paz, 2339'02.85" N, 110³0'11.62" W, 5 m above high tide, 28 June 1996, coastal dunes, José Juan Pérez Navarro 209; specimen with flowers and immature fruit (holotype: HCIB 9054).

Paratypes: Boca del Carrizal, aprox. $1.5 \mathrm{~km} \mathrm{~W}$ of Ejido Melitón Albáñez, La Paz, 19 May 2000, José Juan Pérez Navarro 1251; HCIB 14749. Playa Las Tunas, near arroyo La Bayita, Todos Santos, La Paz, 29 September 2000, José Juan Pérez Navarro 1351, HCIB 14748. Arroyo del Rancho La Vieja, $4 \mathrm{~km}$ al S de Punta Conejo, 12 May 2005, José Luis León de la Luz 10781, HCIB 21424.

C. edulis var. glabra differs from the typical variety by the complete absence of trichomes on the leaf surface, sepals, and fruits (Fig. 1). The prostrate habit also occurs in populations of the typical variety when growing near the coast in sandy soil.

Distribution and habitat: Both varieties of $C$. edulis are sympatric, since near the glabrous populations some prostrate individuals of the typical variety occur. However, their recognition as separate varieties is justified by the differences in leaf, flower, and fruit pubescence, although the prostrate habit is likely attributed to soil properties (sand dunes). A population near Punta Conejo $\left(24^{\circ} 03^{\prime} 58.55^{\prime \prime} \mathrm{N}\right.$; $110^{\circ} 59^{\prime} 23.92^{\prime \prime} \mathrm{W}$ ) grows on calcareous soils; there, the individuals are more abundant than those found at the type locality (Boca del Carrizal).

The range of this new variety extends approximately $90 \mathrm{~km}$ in length in a backdune strip of $200-400 \mathrm{~m}$ width (from $23^{\circ} 39^{\prime} \mathrm{N}, 110^{\circ} 28^{\prime} \mathrm{W}$ to at least $24^{\circ} 04^{\prime} \mathrm{N}$; $111^{\circ} 01^{\prime} \mathrm{W}$ ), where individuals of this species can be considered as "sparcely distributed." At this moment, human impacts on this area are limited.

\section{ACKNOWLEDGEMENTS}

We are grateful to Oscar Armendáriz for his excellent illustration of the new variety. We appreciate the courtesies extended by the herbarium curators of SD and 
ENCB. We also appreciate very much the participation of our herbarium colleagues Raymundo and Miguel Domínguez, as well as of the anonymous reviewers of Acta Botanica Mexicana.

\section{LITERATURE CITED}

Brandegee, T. S. 1900. A new Tapirira from Baja California. Zoe 5(4): 78-79.

León de la Luz, J. L., J. J. Pérez Navarro and A. Breceda. 2000. A transitional xerophytictropical plant community of the Cape Region, Baja California. J. Veg. Sci. 11: 555564.

Manchester, S. R. 1977. Wood of Tapirira (Anacardiaceae) from the Paleogene Carno Formation of Oregon. Rev. Paleobot. Palyno. 23: 119-127.

Shreve, F. and I. L. Wiggins. 1964. Vegetation and flora of the Sonora Desert. 2 vols. Stanford University Press. Stanford. 1740 pp.

Standley, P. C. 1923. Anacardiaceae. In: Trees and shrubs of Mexico. Contr. U.S. Natl. Herb. 23(3): 655-672.

Terrazas, T. and T. Wendt. 1995. Systematic wood anatomy of the genus Tapirira Aublet (Anacardiaceae): a numerical approach. Brittonia 47: 109-129.

Turner, R. M., J. E. Bowers and T. L. Burgess. 1995. Sonoran desert plants: an ecological atlas. University of Arizona Press. Tucson. 504 pp.

Wiggins, I. L. 1980. Flora of Baja California. Stanford University Press. Stanford. 1025 pp. 